\title{
What kind of "Judean" was Jesus?
}

\author{
Markus Cromhout (Johannesburg) ${ }^{1}$ \\ Research associate: Faculty of Theology \\ University of Pretoria
}

\begin{abstract}
Reconstructions of the historical Jesus are analyzed in terms of a proposed socio-cultural model of Judean ethnicity. At first an overview is given of the work of Meier and Crossan to establish the content they assigned to Jesus' Judean ethnicity. Drawing on the insights of ethnicity theory, biblical scholarship and the work of Berger and Luckmann, a socio-cultural model of Judean ethnicity is proposed and explained. The reconstructions of Meier and Crossan are then compared with the proposed model. It is argued that none of their reconstructions allow for Jesus to be seen as profoundly Judean.
\end{abstract}

\section{INTRODUCTION}

This article is a follow-up on two previous articles that investigated Meier $(1991 ; 1994 ; 2001)$ and Crossan's $(1991)$ reconstructions of the historical Jesus (see Cromhout 2006a, 2006b). It was investigated what content they assigned to the "Jewish" ethnic identity of Jesus. What continuities and discontinuities existed between their Jesus and traditional or mainstream "Judaism"? At the same time it was argued that we could not determine what kind of "Jew" Jesus was since none of them gave some analytical framework by which "Jewishness" could be understood and measured. This article aims to rectify this shortcoming and will analyze their Jesus in view of ethnicity theory and a proposed socio-cultural model of Judean ethnicity. The proposed model therefore attempts to provide an analytical framework by which first century Judean ethnic identity can be understood. It can also be used to determine who was "deviant" form the norm. This model will hopefully in some way contribute to solve the dilemma in that much is being said about "Jewishness" in scholarship but it is guilty of not understanding what it really means.

\footnotetext{
${ }^{1}$ Markus Cromhout (MA, Wits; PhD, UP) is a research associate of Prof $\mathrm{Dr}$ Andries G van Aarde, Professor Emeritus, Department of New Testament Studies, Faculty of Theology, University of Pretoria.
} 
Before we continue, however, it should be questioned if we should speak of "Jewishness" in the first century. As can be seen the proposed model is called the socio-cultural model of Judean ethnicity. It is designed to help understand "Judeanness". Here I follow the line of reasoning that it is anachronistic to speak of "Jews" or "Judaism" in the first century. As the people under consideration were territorially rooted in Judea, it is far more accurate to speak of "Judeans" and "Judeanism" (cf Pilch 1997; Esler 2003:63-72; BDAG 2000). Hence the title of this article: "What kind of 'Judean' was Jesus?" To refer to Jesus or his co-ethnics as "Jews" is an analytical filter that is misleading, distorting their identity, their culture, and their particular historical situation. So in what follows, any references to "Jews" and "Judaism" in the work of Meier and Crossan are deliberately replaced with "Judean" and "Judeanism". It makes little or no difference in terms of the content of the analyses offered here, but to understand the content as elements of Judeanism is an important and vital analytical adjustment. It is more true to the ethnic character of the period under consideration.

So this article aims to understand the nature of Jesus' Judeanness in the reconstructions of Meier and Crossan (bearing in mind they understand Jesus as a "Jew"). If we compare their Jesus with the proposed model, what kind of Judean emerges when compared with the mainstream Judean identity of the day? Before we look at this, however, a short overview of the previous articles will be given, explaining the most salient features of Meier and Crossan's reconstructions in terms of the content they assigned to the ethnic identity of Jesus, combined with a few observations of my own.

\section{AN OVERVIEW: THE HISTORICAL JESUS OF MEIER AND CROSSAN}

\subsection{John P Meier - Jesus a marginal "Jew"}

The work of Meier is not yet complete, as a fourth and presumably a final volume is still to come. Based on the work Meier has produced so far, he interprets Jesus as an eschatological prophet continuing in the eschatological tradition of John the Baptist, but with a different emphasis. Where John announced imminent judgement, Jesus announced the imminent arrival of the "kingdom (= rule or reign) of God". This entailed participation for all Israel including sinners - and Jesus understood that God's reign was already partly present in his own ministry and miracle working. So in preparation for the kingdom proper, Jesus set out to restore the twelve tribes of Israel. But how did this eschatological prophet live out his Judean identity? 
In Meier's reconstruction of the historical Jesus, we consistently found a pattern of continuity and discontinuity with traditional Judeanism. We will first have a look at what is continuous between Jesus and Judean ethnicity. If we look at the names of Jesus and his family, they are all derived from the time of the patriarchs, the Exodus and entrance into the Promised Land. This suggests that Jesus' family participated in the reawakening of Judean national and religious feeling in Galilee (Meier 1991:207-208). Jesus would have spoken Aramaic, as most Judeans of Palestine would have, but would also have learned Hebrew and acquired some literacy from Joseph or someone in the local synagogue. Jesus would have been able to read the Hebrew Scriptures and expound it. His religious formation was immense and received an "elementary" education learning the religious traditions and texts of Judeanism. But Jesus would also have acquired limited skill in Greek (Meier 1991:255-268, 274-278), but many Judeans, both of Palestine and the Diaspora, would have known Greek. Jesus' Galilean background was generally conservative in nature, and surrounded by Gentiles, Galileans clinged to the basics of their religion and culture to reinforce their identity (Torah, circumcision, Sabbath observance, purity and food laws and pilgrimage to the Temple) (Meier 1991:277; 1994:1039-1040; 2001:617). The type of Judeanism they followed also held onto certain key beliefs. As the one true God's chosen people, he led them out of slavery during the exodus, made a covenant with them and gave them the land as a perpetual inheritance. After the exile, he also gave them a promise of a future and glorious renewal (Meier 2001:617). Jesus would have received special attention from his putative father Joseph, and in addition to seeing to Jesus' religious education, would also have taught him his own trade as a woodworker (Meier 1991:276, 280-285, 317). Overall, the childhood circumstances of Jesus in Galilee were conducive to fostering a strong Judean ethnic identity.

The adult Jesus went to John the Baptist and received his once-off ritual immersion in water, something he saw as divinely inspired. This implies that Jesus accepted John's eschatological message and saw himself as part of sinful Israel (Meier 1994:110, 123, 163-167). Both Jesus and John the Baptist worked as prophets within and for Israel (Meier 1994:29). Jesus chose a circle of Twelve intimate disciples, something that symbolised Jesus' hope for a regathered and reconstituted Israel. Jesus saw his mission as only directed at Israel, and had but passing contact with Gentiles and Samaritans. For Jesus, there can be no kingdom of God without a complete Israel (Meier 2001:137, 152-153). God will also honour his commitment to Israel and the 
covenant since the patriarchs and faithful Israelites will through the resurrection share in a life similar to the angels (Meier 2001:443).

Jesus shared with the Pharisees a consuming desire to bring all Judeans to a faithful obedience of the Torah. Jesus takes the Mosaic Law for granted as the normative expression of God's will. Jesus also shared with them (by implication Judeans in general) a belief in Israel's divine election, and God's faithful guidance in history to its eschatological restoration (Meier $2001: 338$ ). Along with mainstream Judeanism Jesus also revered the Temple as the one holy place chosen by God for lawful sacrifice, and followed its annual festivals - but the Temple is according to Jesus, part of the present order of things (Meier 2001:499-501, 529).

This brings us to those aspects where Jesus stood in discontinuity with traditional Judeanism. When Jesus went on his itinerant mission, Jesus broke away from his family. He defined a new identity and social role for himself (Meier 1991:317). Jesus also made stringent demands on his followers obligations to home and parents, the social unit that formed and maintained your identity, they must be willing to leave behind. Commitment to Jesus is more important. It is those who do the Father's will who are Jesus' family; his brother, sister and mother (Meier 2001:50-71). This alternative kinship pattern caused family divisions, but Meier unfortunately does not explain what impact this could have had on the patriarchal family as an institution.

By accepting John's message and Baptism, Jesus accepts that physical descent from Abraham - even for the devout - will mean nothing at the coming judgement. It is only by a confession of sin, baptism, and a profound change of heart and conduct that one will be saved. This salvation is available outside the normal channels of Judeanism (the Law, Temple and priesthood etc), which brings into question its sufficiency (Meier 1994:29-30), which should therefore result in the sufficiency of ethnic status as it operated then. Covenant status and divine election has moved beyond traditional Judean ethnic identity.

In his own ministry, Jesus continued with John's baptism. He also grouped himself along with John over and against their Judean contemporaries ("this generation"), and condemns them for not heeding their message (Meier 1994:123, 149, 163-167). The law and the prophets functioned up until John, but from then onwards it was the kingdom that had broken onto the scene (Meier 1994:160-163). What has usually defined Judean ethnicity has now on its own become irrelevant, and is appropriated towards the demands of the kingdom.

When the kingdom of God will fully come, Gentiles will also sit and eat with the patriarchs at the eschatological banquet, while some of Jesus' 
contemporaries will be thrown out (Meier 1994:314-315). Gentiles will therefore be present within the Israelite ancestral land. This also illustrates that the kingdom will go beyond a political kingdom reserved for Judeans (Meier 1994:317; 2001:438-439). At the judgement, the Queen of Sheba and the Ninevites will witness against and condemn that generation. Meier does not explain what kind of Judean Jesus envisions for this future period. Supposedly Meier's Jesus does not see the future kingdom as a celebration of Judean ethnic identity. Also, the implications for Law observance and ownership of the land Meier does not explain.

This future kingdom is in a sense already present through Jesus' healings and table fellowship (Meier 1994:454, 966). Jesus does not fast, and enjoys having table fellowship with Israelites, including tax collectors and sinners, the religious outcasts of Judean society, to enact participation in God's salvation for all Israelites (Meier 1994:966; 2001:524-529). The sinners especially qualified to be regarded as being outside that privileged realm of Judean identity, and here Jesus shows little regard for purity and food laws. Jesus has a very inclusive approach and is not interested to set up boundaries between his own group and other Judeans (Meier 2001:529-530). Combined with Jesus' shocking behaviour around the meal table, Jesus ignored rules concerning the family, and sometimes gave new and startling laws (Meier 2001:338, 340). He also touches lepers when performing a cure. It is difficult to reconcile this Jesus with one that had a consuming desire (along with the Pharisees) to bring all Israel to a complete obedience of the Law. In some exceptional cases, Jesus also performed miracles for Gentiles, pointing to the future offer of salvation for them (Meier 1994:660). And lastly, Jesus acted and said something about the Temple that implied its destruction - it is not clear whether Jesus thought it would be rebuilt in some way (Meier 2001:501).

Does the above overview qualify Jesus to be a marginal Judean? Jesus appears to be very "Judean" and "unJudean" in the same breath. Whether this qualifies Jesus as a "marginal Judean" remains to be seen, however. And how can the eschatological prophet of Israel, the fulfilment of all Israel's hopes and expectations be a "marginal Judean"? Meier's interpretive paradigm where emphasis is placed on Judeanism as a religious identity also needs to be adjusted. Judeanism was not a religious identity - it was an ethnic identity, something that will be explored in further detail below. Understanding Judeanism as an ethnic identity and providing an analytical framework for it will also help us to understand more accurately what kind of Judean Jesus was. 


\subsection{John D Crossan - Jesus a Mediterranean "Jewish" peasant}

As the previous investigation showed, Crossan's approach to the historical Jesus is heavily influenced by the social sciences or the insights of cultural anthropology. Crossan puts Jesus and first century Palestine into the larger context of the "Brokered (Roman) Empire", which entailed the normal features of honour and shame, patronage and clientage. Jesus himself broke away from John the Baptist's eschatological message and announced the brokerless kingdom of God available to all in the present. For Crossan, the heart of the Jesus movement was a shared egalitarianism of spiritual and material resources. Jesus also moved within the realm of inclusive Hellenistic "Judaism", or should we rather say "Judeanism". The implications for Jesus' "Judeaness" based on Crossan's reconstruction is what concerns us here.

Crossan's reconstruction had very little that connected Jesus with traditional Judean ethnicity in the first century. (Of course, Crossan's historical Jesus would stand in continuity with his notion of inclusive Hellenistic "Judaism".) Jesus appeared more as a peasant Mediterranean philosopher than a peasant Judean prophet or sage, and his Judean background is stretched very thin over the ethos of the Roman-Hellenistic empire. Where continuity exists is Jesus' faith in God, but not the God peculiar to Israel as such, since Greeks and Romans can also know God albeit under different names (Crossan 1991:419-420). Nazareth was also a Judean village, but it must be seen as in cultural continuity with Sepphoris and its Hellenised traditions (Crossan 1991:19). In addition, Jesus illustrates a strong community solidarity with socially marginalized Judeans, but one gets the impression this is ideologically not reserved for Judeans alone. There is an openness that could potentially even include the "sinners" and the Gentiles.

Besides the above, after Jesus was baptised by John, Jesus broke away from his eschatological message and concerned himself with the brokerless kingdom of God that is available in the present. It involves those people who place themselves under divine rule - it is not dependent on a nation or place (Crossan 1991:232-238, 266). Jesus obviously had no concern of Judean hopes for ownership of the land.

Jesus challenged the legitimacy of the Temple's spiritual power and engages in religious banditry. For Crossan, Jesus was a magician, personal and individual power in opposition to priest or rabbi as communal and ritual power (Crossan 1991:157-158). Through Jesus' healings/magic, he is placed on par or even above the authority of the Temple, and he implicitly forgives the beneficiaries their sins. He touches lepers and makes them "clean", and so serves as an alternative or negation of the Mosaic purity regulations. The Temple is seen as a source of victimization (Crossan 1991:322-326). For 
Jesus, the Temple and priesthood are not divinely appointed institutions in need of restoration or the neccesary means by which covenant membership (= Judean ethnic identity) can be restored as prescribed in the Torah.

Overall, Jesus ignores purity rules. In his open commensality, Jesus shows he has no interest in making appropriate distinctions and discriminations. He negates the value of food taboos and table rituals (Crossan 1991:262-63). Judeans of different classes and sexes are free to eat together, their ritual status being irrelevant. In various ways, Jesus did not care about some aspects of the Law, which can be understood for our purposes as the "constitution" of Judean ethnic identity. Hence Jesus subverted Judean ethnic identity on more than one level.

When magic and meal come together, the "mission" of Jesus (and his followers) to enact the brokerless kingdom requires a peculiar dress code, in some ways similar (yet different) to Greco-Roman Cynicism (Crossan 1991:332-348). Jesus and his followers are (barefoot?) itinerants as opposed to the localised Temple. Jesus serves as the Temple's functional opponent, alternative and its substitute (Crossan 1991:355) - by implication, also to the Torah in some respects. When Jesus was in Jerusalem he symbolically destroyed it and said he would destroy it beyond repair (Crossan 1991:359360). Jesus therefore saw no need for pilgrimage festivals, and commemorating the Exodus, Passover or other agricultural feasts, all in some way celebrating the redemptive history of Israel. The open commensality of Jesus also demonstrates that Jesus and his followers were redefining Judean ethnic identity based on a spiritual, social and economic egalitarianism.

Jesus was also against the brokered and patriarchal family. He brought division between the generations, and set a wife against her husband - similar tension Jesus experienced with his own family. Jesus sets up an alternative kinship pattern based on egalitarian principles (Crossan 1991:299-302).

Lastly, Jesus moved within the ambience of inclusive Hellenistic Judeanism's synthesis of Judean and Gentile tradition, a popular praxis that might be termed a "Judean" ("Jewish") Cynicism. Unfortunately, Crossan does not give a detailed picture of what inclusive as opposed to exclusive Judeanism involved. In the very least, inclusive Judeanism recognised that it had common ground with some Gentile traditions, such as the understanding of God and questions of morality. Overall, Jesus is a peasant Judean Cynic, who sets the kingdom - a religious, social and economic egalitarianism not dependent on place or nation - in opposition to the Mediterranean and Judean ethos of honour and shame, patronage and clientage. The egalitarianism of Jesus negated at once the hierarchichal and patronal normalcies of Judean religion (Crossan 1991:421-422). The Judean 
"constitution", the Torah, particularly its ritual aspects, is under attack. Jesus appears to be "universally spiritual" and less Judean as such.

So if Jesus was a peasant Judean Cynic, a counter-cultural figure, what does that mean for Jesus' ethnic identity? Crossan by no means denies that Jesus was a Judean ("Jew"), yet his reconstruction with a very strong element of discontinuity with traditional Judeanism do have some strong implications for Jesus' Judean identity. A counter-cultural and Hellenised figure such as Jesus, in opposition to a hierarchical and brokered Judeanism as he was, needs to be analysed in terms of an overall interpretive framework, or a guideline that more or less gives guidelines for a common Judeanism. It is to this analytical framework, a proposed socio-cultural model of Judean ethnicity, that we will turn next.

\section{THE SOCIO-CULTURAL MODEL OF JUDEAN ETHNICITY}

\subsection{Ethnicity Theory}

At first a short overview of ethnicity theory will be given, before the model itself is explained. Ethnicity theory, part of cultural or social anthropology, is a relatively new form of science and is a burgeoning enterprise due to the reality of modern ethnic conflict and resurgence in ethnic affiliation in most parts of the world. But what is ethnicity? There appears to be no universal definition as to what ethnicity (or "ethnic identity") is, although in some writings, a degree of overlap is discernable. ${ }^{2}$ To give a somewhat abridged definition here, ethnicity is a form of social identity, referring to a collectivity of individuals who ascribe to themselves and/or by others, a sense of belonging and a common cultural tradition. The cultural tradition may in various combinations make use of and/or be dependent on a common name, a shared ancestry, a shared historical tradition, having common phenotypical or genetic features, a link to a specific territory, a shared language or dialect, kinship patterns, customs,

\footnotetext{
${ }^{2}$ It has been variously described as the "social organization of culture difference" (Barth 1969); or an "ethnic group is a self-perceived group of people who hold in common a set of traditions not shared by others with whom they are in contact. Such traditions typically include 'folk' religious beliefs and practices, language, a sense of historical continuity, and common ancestry or place of origin ... [T] he ethnic identity of a group of people consists of their subjective symbolic or emblematic use of any aspect of culture, in order to differentiate themselves from other groups" (De Vos 1975:9, 16); or "ethnic identity can best be defined as a feeling of belonging and continuity-in-being (staying the same person(s) through time) resulting from an act of self-ascription, and/or by others, to a group of people who claim both common ancestry and a common cultural tradition" (Roosens 1994:84); or as a last example, ethnic communities may be defined "as named human populations with shared ancestry, myths, histories and cultures, having an association with a specific territory and a sense of solidarity" (Smith 1986:32).
} 
and a shared religion (cf Duling 2005). Jenkins (1997:165) has proposed a "basic social anthropological model" of ethnicity, which is as follows:

- Ethnicity is about cultural differentiation [it involves the communication of similarity and difference];

- Ethnicity is concerned with culture - shared meaning - but is also rooted in, and the outcome of, social interaction;

- Ethnicity is no more fixed than the culture of which it is a component, or the situations in which it is produced and reproduced;

- Ethnicity is both collective and individual, externalized in social interaction and internalized in personal self-identification.

From the above it may be inferred that ethnicity is essentially about cultural differentiation. But exactly how are ethnic groups formed and maintained? Initially, two major theoretical approaches to ethnicity were proposed; namely, Primordialism and Constructionism (Duling 2005:126-27). We shall first examine the former.

Primordialism, associated with Edward Shils (1957a; 1957b) and Clifford Geertz (1963), stresses that "ethnic groups are held together by 'natural affections'. These are bonds so compelling, so passionate, so 'coercive', and so overpowering, that they are fixed, a priori, involuntary, ineffable, even as 'sacred'. These bonds are deeply rooted in family, territory, language, custom, and religion" (Duling 2005:126). They are, in a word, "primordial". ${ }^{3}$ In this instance one's ethnic identity "may not be so much a matter of choice, still less rational choice, but of tradition and emotions provoked by a common ancestry" (Esler 2003:45). It is thought that individuals acquire such primordial bonds "through early processes of socialization" and "such attachments have an overwhelming power because of a universal, human, psychological need for a sense of belongingness and self-esteem" (Jones 1997:66). But what also comes into play here is the role of affect, "the powerful influence of familiarity and customariness in social life, and the diffuse sense of attachment that flows from circumstances of birth and socialization, use of language and ingrained habits of thought and social practice" (Fenton 2003:89). Particularly important here is the role of the family or kinship patterns in identity formation, and particularly in a context where

\footnotetext{
${ }^{3}$ Fenton (2003:83) points out, however, that neither Shils nor Geertz themselves were defining ethnicity. They merely pointed out that some relationships (family, religion, language, customs etc) had a distinctive - primordial - quality when compared with others, such as your relationship with the state.
} 
ethnic differentiation is prominent (Jenkins 1997:47, 58-59). ${ }^{4}$ This approach emphasizes the view of the participant, or how ethnic groups themselves understand reality (i e an insider or emic perspective). From an etic (or outsider) perspective, however, primordialism brings to attention the emotional and psychological strength of ethnic affiliation.

Constructionism or the self-ascriptive approach to ethnicity ${ }^{5}$ associated with Frederik Barth (1969; cf Barth 1994:12), became the major alternative to primordialism (others would say it is instrumentalism - see below). Barth initially argued that the "cultural stuff", although important for social boundaries, is "not as important as the act of social boundary marking itself" (Duling 2005:127; emphasis original). Constructionists took this further and argued that "ethnic identity is not inherent, fixed, or natural; rather, it is fluid, freely chosen, and thus can be seen to be perpetually constructed, that is, continually reconstructed" (Duling 2005:127; emphasis original). The emphasis shifted to how and why ethnic groups create and maintain their group boundaries. In this case the boundary between an ethnic group and outsiders is more of a process than a barrier, thus "cultural features of the ethnic group are the visible and variable manifestation, but not the cause, of an ethnic boundary and identity .... [C]ultural indicia might change over time and yet the ethnic group could still retain a sense of its own distinctiveness" (Esler 2003:42-43). Therefore, in this approach it is important to remember that cultural features do not constitute, but signal ethnic identity and boundaries. An ethnic identity is maintained but with no necessary relation to specific cultural content - the ethnic identity is self-ascriptive, continuously renewed and renegotiated through social practice (Esler 2003:42, 47).

A major development based on constructionism is instrumentalism, where an ethnic group's self-construction is rational and self-interested and deliberately mobilized in an attempt to further its own political-economic agenda (Duling 2005:127; Esler 2003:46).

Overall, the constructionist (or self-ascriptive) approach has become the dominant theoretical perspective on ethnicity, even though most people regard their cultural practices as deeply rooted in antiquity (Avruch 2003:72;

\footnotetext{
${ }^{4}$ Jenkins, however, avoids using the term "primordial". Where ethnic identity is sufficiently salient to be internalized during early primary socialization, ethnicity can be characterized as a primary - not primordial - dimension of individual identity (Jenkins 1997:47).

${ }^{5}$ Variants or developments of this approach to primordialism are referred to as "circumstantialist" (which incorporates the "situationalist"/"instrumentalist" approach), and "transactionalist". The circumstantialist approach views ethnic identity as important in some contexts, while not important in others. The identity is constant but circumstances determine whether it matters (Fenton 2003:84). At times circumstances lead to the rational strategic selection of ethnic identity, as a means to achieve desired political, economic, and other social ends ( $\mathrm{i}$ e the situationalist/instrumentalist approach) (Scott 1990:148).
} 
Jenkins 1996:814; Jones 1997:84). Duling (2005:127) also explains that most theorists agree that people ascribe their ethnicity to themselves (constructionism), but there is still great interest in the "cultural stuff". There is also still wide disagreement on whether self-constructed ethnicity is "irrational and ineffable" (primordialist) or "rational and self-interested" (instrumentalist). The problem has been that primordialism and constructionism/instrumentalism were basically regarded as mutually exclusive, exaggerating the differences between Geertz and Barth whilst also misrepresenting their views somewhat. Hence the reaction to primordialism: ethnicity is not "fixed", or "pre-social" and it is subject to change; hence the reaction to constructionism/instrumentalism: ethnic attachments are sometimes stubborn and also exists before any boundary between "us" and "them". But as Jenkins points out, the approaches of Geertz and Barth have as much in common as what separates them (Jenkins 1997:45, 48; 1994:8, 12-13). So although it is universally agreed that ethnic identity is socially constructed ( $\mathrm{i}$ e it is not "natural", "pre-social" or rooted in human biology), there appears to be a growing recognition among ethnicity theorists that some form of reconciliation or intermediate position is necessary between the constructionist approach on the one hand (particularly its emphasis on the fluid and free transactional nature of ethnicity across the "boundary"), and on the other, the primordial dimensions of ethnicity and/or the importance of cultural content (Hutchinson \& Smith 1996:9; Fenton 2003:111, 194-95; Jenkins 1997:121-22). There have been attempts to integrate the various approaches (e. g. Scott 1990) and it is also suggested that both perspectives are continuously present, but to varying degrees (Jones 1997:80). For our purposes here, primordialism and constructionism/instrumentalism are therefore not seen as mutually exclusive in line with recent approaches. The interaction across the "boundary" cannot be separated from the cultural contents of ethnicity (Jenkins 1997:121-22) and/or its "primordial" dimensions (Scott 1990:149).

The approach taken here is also based on that of Jones (1997:87-105) who appropriated a concept known as the habitus first developed by Bourdieu (1977) in terms of a theory of practice and then applied to ethnicity by Bentley (1987). For Jones this approach overcomes the primordialist and instrumentalist dichotomy. Bourdieu's habitus is made up of durable dispositions (or "unreflexive habit" [Jenkins 1994:203; 1997:58; 2003:64]), that produce certain perceptions and practices that "become part of an individual's sense of self at an early age, and which can be transposed from one context to another ... As such, the habitus involves a process of socialization whereby new experiences are structured in accordance with the structures produced by past experiences, and early experiences retain a particular weight" (Jones 


\section{What kind of "Judean" was Jesus?}

1997:88). So the habitus are both "structuring structures" and "structured structures", which shape, and are shaped by social practice (Jones 1997:89). When applied to ethnicity, "it can be argued that the intersubjective construction of ethnic identity is grounded in the shared subliminal dispositions of the habitus which shape, and are shaped by, objective commonalities of practice ... The cultural practices and representations that become objectified as symbols of ethnicity are derived from, and resonate with, the habitual practices and experiences of the people involved, as well as reflecting the instrumental contingencies and meaningful cultural idioms of a particular situation" (Jones 1997:90). Hence the cultural features employed by an ethnic group are neither purely primordialist (irrational and ineffable) nor purely instrumentalist (rational and self-interested), but a combination of both.

It needs to be mentioned that Jenkins also brings into focus that the "sense of self", located in the habitus, is much influenced by categorization. "Entering into ethnic identification during childhood is definitively a matter of categorization: we learn who we are because, in the first instance, other people - whether they be co-members or Others - tell us. Socialization is categorization" (Jenkins 1997:166; emphasis original). Where ethnicity is important, a child will not only learn she is an " $X$ ", but also what it means: "in terms of her esteem and worth in her own eyes and in the eyes of others; in terms of appropriate and inappropriate behaviour; and in terms of what it means not to be an ' $X$ ' ..." (Jenkins 1997:59; emphasis original). This "sense of self" may continue into adulthood. This would be particularly relevant to the first century personality where the "dyadic" individual or group-orientated personality would always see him or herself through the eyes of others (Malina 1993). The insights of Malina can certainly be appropriated to an individual's sense of ethnic identity. For our purposes here, the "sense of self" and group-orientated personality, and the reciprocal relationships and categorization that it implies, form important elements of the habitus.

\subsection{The Socio-cultural model of Judean ethnicity}

Now the proposed model (see graphic) utilizes the insights of social or cultural anthropologists as outlined above, but it is also represents a synthesis of Sanders' $(1977 ; 1992)$ proposal of covenantal nomism when redefined as an ethnic descriptor ( $\mathrm{i}$ e it functions to describe an ethnic identity, not a religious system), Berger \& Luckmann's (1967) notion of a "symbolic universe", Dunn's (1990; 1991; 2003) "four pillars of Second Temple 'Judaism"' and his "new perspective" on Paul, as well as Duling's (2005) Socio-Cultural Model of Ethnicity (see Cromhout \& Van Aarde 2006). It is a model that attempts to 
serve as a guide for "Judeanness". In other words, it attempts to model mainstream first century (Palestinian) Judean ethnic identity. This is to address the problem identified by Holmén in that the "crucial problem of the 'Third Quest' seems to be that it is not the least clear what 'Jewishness' means. Indeed, judged on the basis of different scholarly pictures of Jesus it can mean almost anything" (Holmén 2001:154; emphasis added). Holmén (2001:161) goes on to explain:

The guidelines for basic or common Judaism would not question the diversity of first-century Judaism, neither would they question Jesus' Jewishness. But the guidelines would enable us meaningfully to evaluate just how he was Jewish by justifying the positing of pictures of Jesus varying from the commonly Jewish to the marginally Jewish. We could again assess whether Jesus was, for example, profoundly Jewish or a "different kind of Jew".

The model, of course, is designed to help assess whether Jesus (or anyone) was profoundly Judean or a "different kind of Judean". While it models first century Judean ethnic identity, it also functions to serve as a pictorial representation of the Judean "symbolic universe" where all Judean institutions are integrated into an all-embracing and sacred frame of reference. The proposal for a guideline for a basic or common Judeanism looks as follows: 


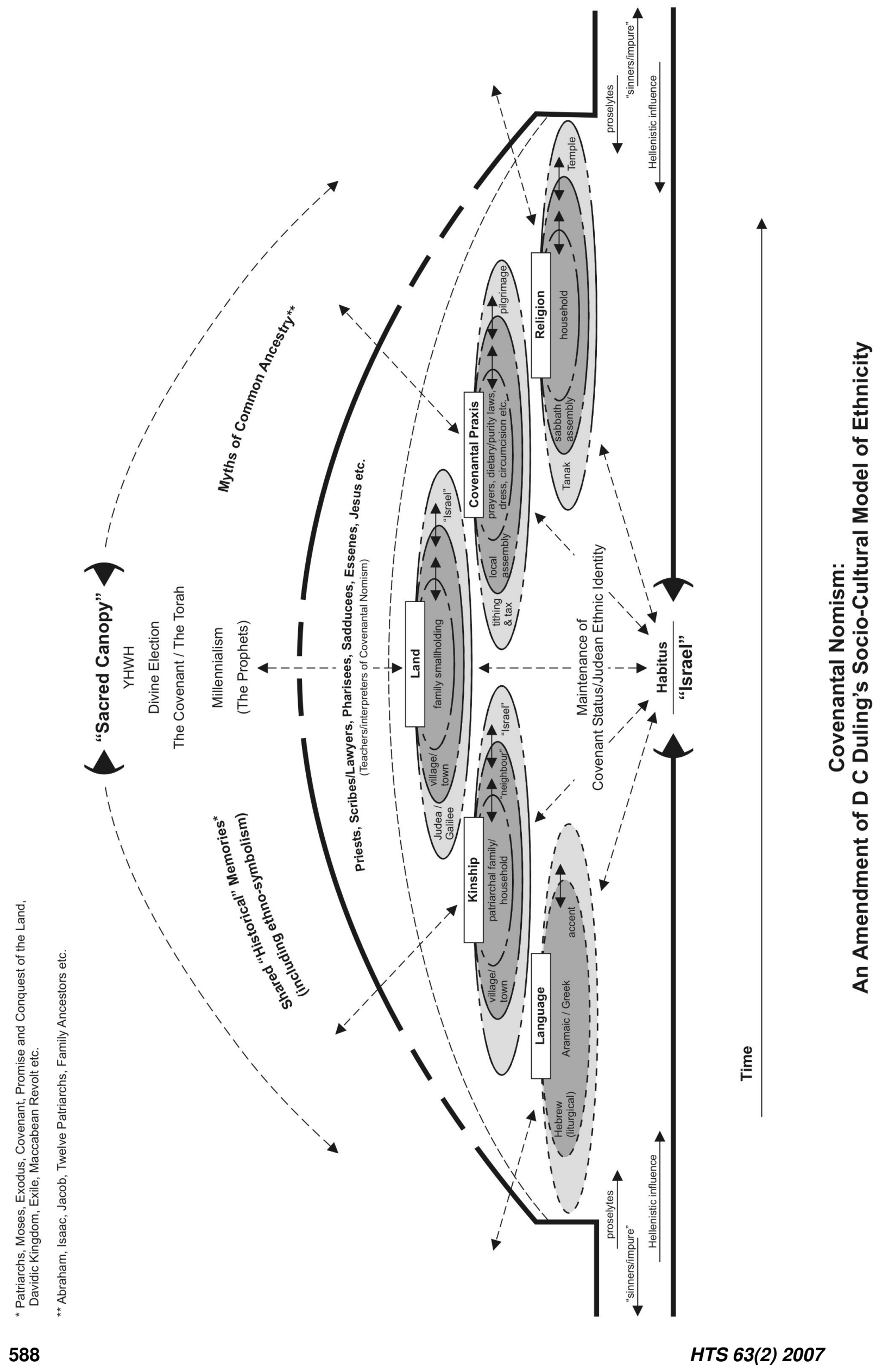


The socio-cultural model of Judean ethnicity admittedly is a modern construct, "imposed" on the available data. The model bears the appropriate name of "Covenantal Nomism". The name describes the entire process of Judean ethnic identity formation in a nutshell, how a group of people become Judean, and how they stay that way. The model therefore corresponds to these two dynamics by consisting of two main areas, namely, the "Sacred Canopy" and the "Habitus/Israel". The "Sacred Canopy" is primarily the dimension in the model dealing with God who established (in the past), and continues to prescribe (in the present), Judean ethnicity through his divine election, the covenant, and gift of the Torah ("getting in"). The "Habitus/lsrael" (which extends to include more tangible cultural features), refers to a group of people, Israel, responding to that call by being Judean ("staying in"). The Habitus/Israel will be discussed in further detail first.

\subsubsection{The Habitus/lsrael}

Judean ethnicity is the result of socialization. First, it is grounded in the habitus, the shared habitual dispositions of Judean social agents, or in short, "Israel", which shape and are shaped by objective common cultural practices. Here we enter the realm of affect, the powerful influence of familiarity and customariness in social life, and the strong attachments that result from ingrained habits of thought and social practice (cf Fenton 2003:89-90). Second, within the habitus the "sense of self" is internalized through categorization, be it through the family, the village/town, or through society as a whole. In this regard, the identity of the individual as a group-orientated personality, and his/her sense of belongingness and self-esteem form important elements. Here we enter the realm of origins and history, tradition, shared values and meaning.

The Habitus/Israel primarily constitutes the dialectical interrelationship between the habitus and the more tangible institutions or cultural features of Judean ethnicity, which collectively, is contained within the thick black lines. This interrelationship is dominated by the endeavor to respond to God's divine election and to maintain covenant status or Judean ethnic identity ("staying in"). Being grounded in the habitus, the interrelationship produces Judean ethnic identity, which involves the objectification of cultural practices in the recognition and communication of affinity and difference vis-à-vis other peoples.

Ethnicity theory explains that kinship relations and myths of common ancestry and a certain connection with a homeland are the most widespread of the cultural features. The cultural feature of land is given some prominence 
in the model, as it always was a primary feature of Judean ethnicity, and is related to the very strong hopes of restoration the Judeans had (i e "Millennialism"). Land is flanked by kinship and covenantal praxis ${ }^{6}$ (the latter stands in close association with religion) and which in their own way were also primary sources of identity. But overall, the Habitus/Israel points to Judeans living on their ancestral land, circumcising their sons, eating food according to the laws of kashrut, going on pilgrimage, reciting the Shema, their family ties and communal solidarity and attending the Sabbath assembly and so on. It points to covenantal nomism in action.

The above explains the dialectic relationship between the Habitus/Israel and the immediate cultural features that gave expression to that ethnic identity. It is also argued here that Judean ethnicity was essentially primordialist, meaning, it was made up of elements that for the greater part can be described as "primordial attachments". This is represented by the more solid lines in the model. Judean ethnicity was socially constructed, but ethnicity was always important. Socialization and the objectification of cultural practices (be they "internal" or "external") were governed by the requirements of the covenant and Torah. So it was not simply a matter of habitual dispositions or the role of affect, or a sense of history and tradition, it was also about being obedient to God's will. Judeans did not have the "freedom" to construct their ethnicity as other groups had. Being God's chosen people imposed serious restrictions. So the extreme constructionist idea that "cultural features of the ethnic group are the visible and variable manifestation, but not the cause, of an ethnic boundary and identity" (Esler 2003:42) is hardly applicable to Judeanism.

In addition, Judeanism formed part of the Roman Empire, hence it was the victim of political and economic oppression and exploitation. A related feature is that Judeanism was under pressure from Hellenism - at one stage it was even persecuted and forced to adopt Hellenistic culture (Maccabean revolt). ${ }^{7}$ Esler (2003:46) himself noted that "members of an ethnic group, particularly one under threat, are far more likely to adhere to a primordialist

\footnotetext{
${ }^{6}$ It was argued previously that Judean "customs" can more appropriately be called covenantal praxis. Judean customs inevitably were a demonstration that their practitioners were Judean, or members of God's covenant people (Cromhout \& Van Aarde 2006).

${ }^{7}$ The Maccabean and other revolts can also be described as a form of ethnicism, "a collective movement, whose activities and efforts are aimed at resisting perceived threats from outside and corrosion within, at renewing a community's forms and traditions, and at reintegrating a community's members and strata which have become dangerously divided by conflicting pressures ... [E]thnicism has manifested three broad aims in antiquity ... territorial restoration, genealogical restoration and cultural renewal" (Smith 1986:50-51). Further, Smith (1986:5556) explains that ethnicism is fundamentally defensive, provoked by military threat, socioeconomic challenges, and cultural contact. All these things can accurately describe the situation of first-century Judeanism, and the period that led up to it.
} 
view of ethnicity" than to an interactive and self-ascriptive (the extreme constructionist) approach, and even less to an instrumentalist one. In this regard Scott has argued that that primordial sentiments will become greater the greater the amount of opposition experienced by that group. He explains further "with respect to the content of ethnic identity, the primordial sentiments will also attach to the symbols against which the greatest opposition is expressed, whether language, territory, heroes, music, dance, cuisine, or clothing, such that they will become even more salient in the individual's reckoning of his or her ethnicity" (Scott 1990:163; emphasis original). And the greater the opposition experienced by the group, the greater its ethnic solidarity becomes, which according to Scott (1990:166), also tends to increase the lower the person's socio-economic status. Ethnic identities also encode relations of power (cf Fenton 2003:113-34; Stein 2004). Judean ethnicity encoded an identity in which reality conflicted with the ideal, in which a dominated people longed for divine deliverance.

Judeanism also had the more constructionist elements to it, however. The laws on clean and unclean foods from the time of the Maccabees took on increasing importance in Judean folklore and Judean self-understanding (Dunn 1990:193). Also, in post-exilic Israel Gentiles could now also convert to Judeanism, while intermarriage was prohibited (Cohen 1987:51, 54). The latter can be regarded as part of the defensive marriage strategy of post-exilic Judeanism as outlined by Malina (1993:134-38). These two examples, however, had their basis in primordialism. Here "primordial attachments" religion, covenantal praxis, kinship/the family - were intensified.

A third example is an exception, which concerns the cultural feature of language. When viewing the model, it is noticeable that it is the only cultural feature that is represented by broken lines, indicating that it was a cultural feature in (re)construction. It is commonly accepted that Aramaic was the everyday spoken language of Palestinian Judeans, but based on the available evidence more and more Judeans spoke Greek, as a second, or even as a first language.

A convenient way of analyzing an ethnic group is also by differentiating between the varying perspectives of those involved with the group. These processes of ethnic identity formation can also be modeled on three separate though connected levels of abstraction: micro, median and macro (Barth 1994; cf Esler 2003:48-49). Briefly, the micro level is concerned with processes that affect the ordinary members of the group. Its focus is on individual persons and interpersonal interaction. It has to do with "the management of selves in the complex context of relationships, demands, values and ideas; the resultant experiences of self-value, and the 


\section{What kind of "Judean" was Jesus?}

embracements and rejections of symbols and of social fellowships that are formative of the person's consciousness of ethnic identity" (Barth 1994:21). The median level is concerned with entrepreneurship, leadership and rhetoric. In this instance processes create and mobilize groups and intervene to constrain or compel people's expression and action on the micro level. Lastly, the macro level concerns itself with outsiders with power over the group. It involves state policies (whether legal or ideological) that allocates rights and obligations, which may involve the use of force and the control and manipulation of public information. These processes of ethnic identity formation are represented in the model, where the micro and median levels are indicated by the darker grey areas, and the macro level by the lighter grey areas. These areas broadly correspond to Malina's "person-sustaining groups" (i e family, village, city and nation). By representing the micro and median level with the same color, I attempted to show how closely connected these two levels are in Judean society.

Lastly, there were those Judeans, predominantly the priesthood, who along with others, acted as teachers or interpreters of covenantal nomism. They were the "experts" whose main task was the maintenance of Judeanism. They were the link between the Sacred Canopy and the Habitus/lsrael. The historical Jesus and the Pharisees functioned here as well.

\subsubsection{The Sacred Canopy}

The second main part of the model concerns the "Sacred Canopy". For lack of a better description, it constitutes the Judean "religion" or "theology". The habitus not only shapes, and is shaped by common cultural practices, but they also shape and are shaped by Israel's common beliefs; that is, the "Sacred Canopy". Not to be forgotten is the role of categorization. This dialectical interrelationship primarily has to do with the belief that Yahweh established/prescribes Judean ethnicity ("getting in"). It therefore also involves the objectification of cultural practices in the recognition and communication of affinity and difference vis-à-vis other peoples. But the sacred canopy represents the more "intangible" aspects of Judean ethnicity, or the furthest reach of Judean self-externalization (cf Berger 1973:37). The sacred canopy concerns that part of covenantal nomism under which all of the system or identity we call Judeanism took shape.

In pre-modern eras a distinctive religion or vision of a world religion proved to be a very strong force in the persistence of ethnic identity (Smith 1994:716). In this regard the sacred canopy points first and foremost to Yahweh, the God of Israel and his election of that people, the covenant and gift of the Torah. Collectively, these certainly constituted a strong force in the 
persistence of Judean ethnic identity. Inseparable from this, however, are shared "historical" memories and the rich ethno-symbolism ${ }^{8}$ contained therein, and the myths of common ancestry. All of these together are an example of a communal mythomoteur, or constitutive political myth of an ethnic group (see Smith 1986:61-68; 1994:716). The community is endowed with sacred qualities, "which may generate an almost messianic fervor in times of crisis, particularly when allied to a heightened sense of superiority and a myth of ethnic election" (Smith 1994:716).

The latter naturally leads into the last element of the furthest reach of Judean self-externalization, namely, Millennialism. Inspired by the prophets, and no doubt contemporary reality, Israel was awaiting God's intervention on their behalf. The future restoration of Israel primarily referred to Israel's independent control and ownership of the land.

\section{SO WHAT KIND OF "JUDEAN" WAS JESUS?}

The question is now how did Jesus operate within and relate to the realm of covenantal nomism (= Judean ethnic identity) as explained above? With the help of the proposed model, we will do an overview of Meier and Crossan's work to see how they are understood to have answered that question. Whether they would endorse this assessment is a matter altogether different, but it is the intention to as objectively as possible take their reconstructions to its logical conclusion. It must be emphasised that not any claims with regards to the historical Jesus are made here, and the analysis below is based on interpretations of the historical Jesus.

\subsection{John P Meier - Jesus a marginal "Jew"}

So where does Meier's Jesus fit on the scale mentioned by Holmén from the commonly Judean ("Jewish") to the marginally Judean? Meier's Jesus appears to be profoundly Judean in some respects while being a different kind of Judean in others. We must bear in mind that Meier's work is yet to be completed, but here is what can be gathered from his work thus far.

\footnotetext{
${ }^{8}$ Ethno-symbolism analyses how an ethnic group's nostalgia about its perceived past expressed through cosmogonic myths, election myths, memories of a golden age, symbols shapes the group's ability to endure, but also to change and adapt (Duling 2005:127). This can be seen in Judean literature (e g Jubilees and Pseudo-Philo) where past traditions are used creatively for the Judean struggle against Hellenism and the maintenance of Judean identity.
} 


\subsubsection{Jesus and the Habitus/Israel}

A few general remarks can be made first. As will be recalled, the names of Jesus and his family hark back to the patriarchs, the Exodus and conquest of the promised land. This means that his family participated in the reawakening of national and religious feeling. Galilee was conservative in nature, and surrounded by Gentile territories, Galileans clinged to the basics of Israelite religion to reinforce their identity. Jesus himself received some basic training, and had the ability to read Hebrew and expound the Scriptures. All of these combine to suggest that Jesus was socialised from a young age into finding his identity as a Judean, and that his sense of belongingness and self-esteem was dependent on how he operated within the Judean symbolic universe. Overall, Jesus grew up in an environment that would have fostered a strong Judean ethnic identity. To put it differently, the social environment of Jesus was essentially primordialist, that is, it was dominated by "primordial attachments" in order for Judeans to differentiate themselves culturally from the surrounding Gentiles.

- Language:

Apart from Hebrew, Jesus would have spoken Aramaic as his everyday language, but had some knowledge of Greek as well although he never attained scribal literacy. Overall, language did not play that of an important role in establishing Judean identity, as many Judeans living in Palestine would have spoken Greek.

\section{- Religion:}

Primordialist tendencies: Jesus shared with the Pharisees a consuming desire to bring all Judeans to faithful obedience to God's will as set out in the Torah. The Mosaic law is taken for granted as the normative expression of God's will.

Jesus also revered the Temple as the one holy place chosen by God for lawful sacrifice. Jesus followed its festivals, although he regarded the Temple as belonging to the present order of things.

(Re)constructionist tendencies: The Law and the prophets functioned up to John the Immerser, from which time the kingdom of God had broken onto the scene. What has defined Judean ethnic identity has now on its own become irrelevant, and is appropriated towards or qualified by the demands of the kingdom. In this regard Jesus gives new and startling laws. He also through his own teaching and demands 
on his followers undermines the Law with regards to the family, but also the food and purity laws are undermined through his inclusive table fellowship and healing. In various ways the kingdom of God stands in tension with the traditional Torah.

The actions and sayings of Jesus pointed to the Temple's destruction, but it is not clear whether he thought it would be rebuilt some day.

- Kinship:

Primordialist tendencies: Jesus operated as a prophet within and for sinful Israel. The mission of Jesus was exclusively aimed at Israel and he had but passing contact with Gentiles and Samaritans. By accepting John's immersion, he demonstrated communal solidarity with a sinful Israel.

(Re)constructionist tendencies: Jesus might have followed his father's trade as a woodworker, but Jesus broke with his family to define a new role and social identity for himself. He made the same demands on some of his followers. Jesus establishes an alternative kinship pattern; those who do the Father's will is Jesus' real family, his mother, brother and sister. Any notion of biological peoplehood based on family and ancestry collapses and is replaced by a spiritual kinship. The Judean symbolic universe is redefined, where faithful Israel (i e those who heed Jesus' message) is opposed to unfaithful Israel.

Jesus has open table fellowship, and this inclusive approach demonstrates no interest to set up boundaries between his own group and other Judeans.

- Covenantal Praxis:

(Re)constructionist tendencies: Jesus received the immersion of John, and so saw himself as part of a sinful Israel. Jesus must have accepted John's message - it is only through confession of sin and baptism, and a profound change of heart and conduct that Israelites will be saved. This was required even of the devout (i e the profoundly Judean). This brings into question the sufficiency of the Judean symbolic universe and Judean ethnic identity as it operated at the time. Covenant status, divine election, indeed ethnic identity, has moved beyond traditional Judeanism. Jesus continued with John's baptism in his own ministry, thereby extending the eschatological dimension of John's message. 
In enacting the presence of the kingdom of God, Jesus enjoys table fellowship with various Israelites, including tax collectors and sinners. Here Jesus demonstrates little concern for purity laws. The kingdom of God represents an alternative symbolic universe, where the socially marginalised are restored into a correct relationship with God through inclusive fellowship and following Jesus - this occurs outside the traditional channels of Torah, priesthood and Temple.

- Land:

Primordialist tendencies: For Jesus, there can be no complete kingdom without a complete Israel. The Twelve disciples symbolised a regathered and reconstituted Israel.

(Re)constructionist tendencies: The future kingdom of God envisages the participation of Gentiles. It will not be a political kingdom reserved for Judeans alone, while unfaithful Israel, even the supposed devout, will be thrown out of the kingdom. The future kingdom will therefore consist of people who heeded the message of Jesus, regardless of their ethnic identity.

\subsubsection{Jesus and the Sacred Canopy}

Primodialist tendencies: Jesus shared the belief in Israel's divine election and God's gift of the Torah. In terms of Millennialism, there can be no kingdom of God without a complete Israel. God will show his faithfulness to Israel and the covenant as the patriarchs and faithful Israelites will share in the resurrection.

$(R e) c o n s t r u c t i o n i s t ~ t e n d e n c i e s:$ When the kingdom of God is established in full, Gentiles will also sit and eat with the patriarchs at the eschatological banquet, while some of Jesus' contemporaries, presumably including the devout, will be thrown out of the kingdom. The Queen of Sheba and the Ninevites will be present and condemn that generation. On occasion, Jesus also performed miracles for Gentiles, which pointed to the future offer salvation for them. The future aspect of the kingdom therefore envisages a symbolic universe where ethnic identity is not a determining factor.

- Shared "historical" memories and myths of common ancestry:

Primordialist tendencies: Jesus chose Twelve disciples, employing this example of ethno-symbolism to point to a regathered and reconstituted Israel. There can be no kingdom of God without a complete Israel. 
Jesus referred to the patriarchs participating in the resurrection, and the symbolism behind the Twelve disciples imply that Jesus ascribed positive value to Israel's epic history. Jesus further shares the belief in God's faithful guidance of Israel through history.

(Re)constructionist tendencies: By accepting the immersion of John, Jesus accepts that physical descent from Abraham, even for the devout, will mean nothing on its own at the coming judgement. Here any notion of ethno-symbolism is used to confront the present understanding of covenant membership and salvation history. Here ethno-symbolism is not used to maintain the status quo, or to help Judeans endure in the current situation. It is used in view of the demands of the future yet present kingdom of God in a challenging way.

\subsubsection{Findings}

Jesus' ethnic identity is therefore a curious and perplexing mixture of primordialism and constructionism. The (re)constructionist element, however, given its content by the demands of the (future yet present in some way) kingdom of God, dominates. There are elements of discontinuity in every cultural feature, besides language, which anyhow does not really play an important role here in terms of our assessment of Meier's historical Jesus. Thus the balance of the evidence makes us understand Meier's historical Jesus as a different kind of Judean. Jesus is an eschatological prophet, who announces the arrival of the kingdom (= rule or reign) of God, an alternative symbolic universe that builds on traditional covenantal nomism, but in some respects undermines it in the process. It will have no room for the "devout"; the kingdom requires the participation of a different kind of Judean.

Particularly the future vision requires different expectations and ways of doing things accustomed to. This kingdom envisages no celebration of Judean ethnic identity exclusive of complete Gentile participation. Covenantal nomism, thus Judean ethnic identity, is in (re)construction, and this process will gather momentum when the kingdom is fully established. In all of this to call Jesus a "Marginal Judean" is being kind. Somehow Jesus "outgrew" the "primordialist" identity of his day. Jesus already in some ways stood aloof from the Judean symbolic universe but nevertheless retained a close contact. Indeed, the Judean symbolic universe is already in the process of being transformed into a universal symbolic universe, which paradoxically, will still focus on geographical Israel. 


\subsection{John D Crossan - Jesus a Mediterranean "Jewish" peasant}

On that scale mentioned by Holmén between the commonly Judean and the marginally Judean, Jesus definitively leans heavily towards the marginal side of the scale. Again, we will do a brief overview of the most salient features.

\subsubsection{Jesus and the Habitus/lsrael}

Jesus grew up in Nazareth, but as a Judean village, it must be seen in cultural continuity with Sepphoris and its Hellenised traditions. Overall Jesus moved within the ambience of inclusive Hellenistic Judeanism and its synthesis of Judean and Gentile tradition. Jesus was therefore socialised into an environment that was not inclined to be primordialist.

\section{- Religion:}

$(R e)$ constructionist tendencies: Jesus challenged the legitimacy of the Temple's spiritual power. In fact, he engages in religious banditry in this regard and sees the Temple as a source of victimisation. Through his healings/magic, which fell in line with the traditions of Elijah and Elisha, he is placed on par or even above the authority of the Temple. He declares the leper as "clean" and so serves as an alternative or negation of Mosaic purity laws. In the process, the beneficiaries of his magic implicitly receive the forgiveness of sins.

The itinerant mission of Jesus and his followers are in opposition to the localised Temple. Jesus serves as the Temple's functional opponent and its substitute. By implication, Jesus opposes aspects of the Torah as well. When Jesus was in Jerusalem, he symbolically destroyed the Temple and said he would destroy it beyond repair.

\section{- Kinship:}

$(R e)$ constructionist tendencies: Jesus demonstrated a strong communal solidarity with marginalised Judeans, but one gets the impression that ideologically, it was not reserved for Judeans alone.

Jesus opposes the brokered and patriarchal family in line with Micah 7:6. He establishes an alternative kinship pattern based on egalitarian principles.

\section{- Covenantal praxis:}

(Re)constructionist tendencies: Jesus was baptised by John, but thereafter he moved away from John's eschatological message to proclaim the brokerless kingdom of God available in the present. 
Jesus ignores purity laws. He negates the value of food taboos and table rituals. According to Jesus, Judeans of different classes and ranks are free to eat together. Their ritual status is irrelevant.

When magic and meal come together in Jesus' itinerant mission to enact the brokerless kingdom, he and his followers adopt a peculiar dress code somewhat similar yet different to Greco-Roman Cynicism.

- Land:

(Re)constructionist tendencies: Jesus preached a non-eschatological message of the brokerless kingdom that is available in the present. It concerns a mode of being. People place themselves under divine rule but it is not dependent on nation or place. Indeed, there is a very strong universal element to Jesus' teaching.

\subsubsection{Jesus and the Sacred Canopy}

Jesus evidently had a profound faith in God, but not necessarily the God peculiar to Israel, for even Gentiles know God albeit different names. As for the rest, not much can be said here. Evidently Jesus did not give any priority to the notions of a common ancestry, a shared historical and cultural tradition, or hopes of Israel's future restoration.

\subsubsection{Findings}

Jesus' ethnic identity is therefore overwhelmingly (re)constructionist. There are elements of discontinuity in every cultural feature when it comes to Jesus. The balance of the evidence makes us understand Crossan's historical Jesus most definitively as a different kind of Judean. When compared with Crossan's other work on Jesus and early Christianity/Messianism (Crossan 1999; Crossan \& Reed 2001), Jesus may be said to stand in continuity with the Tanak's theology of redistributive justice. As for the rest, Crossan's Jesus practically obliterates Judean ethnic particularity. Jesus is a peasant Judean Cynic, who sets the kingdom over and against the brokered and hierarchical Mediterranean, of which Judeanism was a part as well. But overall, the immediate social background of Jesus is stretched very thin over the larger Greco-Roman world. There is very little, if any cultural particularity in the historical Jesus. As can be seen the cultural features of shared "historical" memories and myths of common ancestry does not really function in Crossan's reconstruction. Although Jesus' magic is placed in the tradition of Elijah and Elisha, and Jesus' attack on the family hierarchy is similar to Micah $7: 6$, there is no explicit connection that Jesus makes with the past. Ethno- 
symbolism is virtually non-existent in Jesus' frame of reference. Nothing is said of God's divine election of Israel, or his gift of the Torah, or covenant membership. Evidently Jesus has no concern for the future fate of Israel with regards to its restoration. Had Jesus any notion of covenantal nomism, or Judean ethnic identity, it was in the process of radical (re)construction. If Meier's Jesus in some ways stood aloof from the Judean symbolic universe, Crossan's Jesus is off the radar. He appears more to be a peasant Mediterranean philosopher-like figure, oh, who by the way, happens to be Judean. The present and brokerless kingdom of God involves a countercultural lifestyle with a strong egalitarian social vision, which by accident or design, may potentially involve any person of whatever ethnic background. The symbolic universe in which Jesus operated was truly universal in its scope, which according to this analysis, obliterates ethnic identity altogether.

\section{SUMMARY}

It is interesting to compare Meier and Crossan's reconstructions. Jesus' discontinuity or his (re)constructionist tendency is either explained by his eschatological perspective regarding the future but also present kingdom (Meier) or by Jesus moving within the realm of a counter-cultural inclusive Hellenistic Judeanism (Crossan). But both agree that Jesus to a greater or lesser extent stood in discontinuity with covenantal nomism when compared with the proposed model. As a reminder, the model represents an understanding that covenantal nomism (= Judean ethnic identity) of our period was essentially primordialist. In terms of Jesus' discontinuity, the three cultural features normally regarded as the most widespread or important for ethnic groups are quite telling. Jesus had no pre-occupation for an exclusive and independent political homeland, although "Israel" was where Jesus focussed his mission. Jesus developed an alternative kinship pattern. Belief in a common ancestry was in one respect revered, while on the other subverted since covenant status was no longer dependent on biological ancestry (Meier only).

In terms of covenantal praxis (or customs), again has Jesus at times as straying from the accepted norm. Jesus in (at least some) situations (healing and eating) showed little regard for purity and food laws. Lastly, when it came to religion, in word and deed Jesus anticipated the destruction of the Temple (and generally the Torah observance of Jesus in some respects is scandalous by the norms of the day). On these last two cultural features in particular, Meier and Crossan share what seems to be a broad agreement on Jesus' 
actions (cf Borg1983, 1987; Horsley 1987; ${ }^{9}$ Sanders 1985, 1993; Becker 1998). So in particular instances, when compared with the proposed model in all its aspects, the Jesus produced by historical reconstruction can hardly be described as being profoundly Judean. What both Meier and Crossan suggest in their own unique way is the following: Jesus of Nazareth - and at that moment within Judeanism itself - was covenantal nomism or Judean ethnic identity in (re)construction. Jesus defined a new way of being Judean. He undermined traditional Judean ethnic identity in the process. Importantly, this process of ethnic identity formation was a move in the opposite direction of mainstream Judean ethnicity, which was essentially primordialist in character being dominated by the requirements of the covenant and Torah, and the need for cultural differentiation from the Gentiles. This can potentially help to explain "of how it could be that Jesus lived within [Judeanism] and yet became the origin of a movement that eventually broke with it?" (Paget 2001:151).

\section{Works consulted}

Avruch, K 2003. Culture and ethnic conflict in the new world disorder, in Stone, J \& Dennis, R (eds), Race and ethnicity: Comparative and theoretical approaches, 72-82. Oxford: Blackwell.

Barth, $F($ ed) 1969. Ethnic groups and boundaries. Boston: Little \& Brown.

Barth, $F$ 1994. Enduring and emerging issues in the analysis of ethnicity, in Vermeulen, $\mathrm{H}$ \& Govers, C (eds), The anthropology of ethnicity: Beyond "ethnic groups and boundaries", 11-32. Amsterdam: Het Spinhuis.

BDAG 2000. A Greek-English Lexicon of the New Testament and other Early Christian literature, 3rd ed of BAGD, rev by F W Danker. Chicago, IL: University of Chicago Press.

Becker, J 1998. Jesus of Nazareth, tr by J E Crouch. Berlin: W de Gruyter.

Bentley, G C 1987. Ethnicity and practice. Comparative Studies in Society and History 29, 24-55.

Berger, P L 1973. The social reality of religion. Penguin University Books. Harmondsworth: Penguin.

Berger, P L \& Luckmann, $\mathrm{T}$ 1967. The social construction of reality: $A$ treatise in the sociology of knowledge. New York: Anchor Books.

Borg, M J 1983. Conflict, holiness and politics in the teachings of Jesus. Lewiston: Edwin Mellen.

Borg, M J 1987. Jesus: A new vision: Spirit, culture, and the life of discipleship. San Francisco, CA: Harper \& Row.

Bourdieu, P 1977. Outline of a theory of practice, tr by R Nice. Cambridge: Cambridge University Press.

\footnotetext{
${ }^{9}$ Horsley, however, argues that Jesus did not recruit or specially welcome social outcasts such as tax collectors, sinners, prostitutes, beggars, cripples and the poor. These traditions come from the early Messianist communities. Jesus restored the healed to normal social interaction in their communities.
} 
Cohen, S J D 1987. From the Maccabees to the Mishnah. Philadelphia, PA: Westminster.

Cromhout, M \& Van Aarde, A 2006. A socio-cultural model of Judean ethnicity: A proposal. HTS 62(1), 69-101.

Cromhout, M 2006a. J P Meier's construct of Jesus' "Jewishness": A critical assessment. Ekklesiastikos Pharos 88, 102-29.

Cromhout, M 2006b. J D Crossan's construct of Jesus' “Jewishness”: A critical assessment. Acta Patristica et Byzantina 17, 155-178.

Crossan, J D 1991. The historical Jesus: The life of a Mediterranean Jewish peasant. New York: HarperSanFrancisco.

Crossan, J D 1999. The birth of Christianity: Discovering what happened in the years immediately after the execution of Jesus. San Francisco, CA: HarperSanFrancisco.

Crossan, J D \& Reed J L 2001. Excavating Jesus: Beneath the stones, behind the texts. San Francisco, CA: HarperSanFrancisco.

De Vos, G 1975. Ethnic pluralism: Conflict and accommodation, in De Vos, G \& Romanucci-Ross, L (eds), Ethnic identity: Cultural continuities and change, 541. Palo Alto: Mayfield.

Duling, D C 2005. Ethnicity, ethnocentrism, and the Matthean ethnos. BTB 35(4), $125-143$.

Dunn, J D G 1990. Jesus, Paul and the law: Studies in Mark and Galatians. Louisville, KY: Westminster John Knox.

Dunn, J D G 1991. The partings of the ways between Christianity and Judaism and their significance for the character of Christianity. London: SCM.

Dunn, J D G 2003. Christianity in the making: Jesus remembered. Grand Rapids, MI: Eerdmans.

Esler, P F 2003. Conflict and identity in Romans: The social setting of Paul's letter. Minneapolis, MN: Fortress.

Fenton, S 2003. Ethnicity. Cambridge: Polity.

Geertz, C 1963. The integrative revolution: Primordial sentiments and civil politics in the new states, in Geertz, C (ed), Old societies and new states, 105-57. New York: The Free Press.

Holmén, T 2001. The Jewishness of Jesus in the "Third Quest", in Labahn, M \& Schmidt, A (eds), Jesus, Mark and Q, 143-162. Sheffield: Sheffield Academic Press.

Horsley, R A 1987. Jesus and the spiral of violence: Popular resistance in Roman Palestine. San Francisco, CA: Harper \& Row.

Hutchinson, J \& Smith, A D (eds) 1996. Ethnicity. Oxford: Oxford University Press.

Jenkins, R 1994. Rethinking ethnicity: Identity, categorization and power. Ethnic and Racial Studies 17(2), 197-223.

Jenkins, R 1996. Ethnicity etcetera: Social anthropological points of view. Ethnic and Racial Studies 19(4), 807-22.

Jenkins, R 1997. Rethinking ethnicity: Arguments and explorations. London: SAGE.

Jenkins, R 2003. Rethinking ethnicity: Identity, categorization, and power, in Stone, J \& Dennis, R (eds), Race and ethnicity: Comparative and theoretical approaches, 59-71. Oxford: Blackwell.

Jones, S 1997. The archaeology of ethnicity: Constructing identities in the past and present. London: Routledge. 
Malina, B J 1993. The New Testament world: Insights from cultural anthropology, revised edition. Louisville, KY: Westminster.

Meier, J P 2001 [1994, 1991]. A marginal Jew: Rethinking the historical Jesus, 3 vols. New York: Doubleday.

Paget, J C 2001. Quests for the historical Jesus, in Bockmuehl, M (ed), The Cambridge Companion to Jesus, 138-55. Cambridge: Cambridge University Press.

Pilch, J J 1997. Are there Jews and Christians in the Bible? HTS 53(1\&2), 119-125.

Roosens, E 1994. The primordial nature of origins in migrant ethnicity, in Vermeulen, $\mathrm{H} \&$ Govers, C (eds), The anthropology of ethnicity: Beyond 'ethnic groups and boundaries', 81-104. Amsterdam: Het Spinhuis.

Sanders, E P 1977. Paul and Palestinian Judaism: A comparison of patterns of religion. London: SCM.

Sanders, E P 1985. Jesus and Judaism. London: SCM.

Sanders, E P 1992. Judaism: Practice and belief 63 BCE-66 CE. London: SCM.

Sanders, E P 1993. The historical figure of Jesus. Harmondsworth: Penguin Books.

Schmidt, F 2001. How the temple thinks: Identity and social cohesion in Ancient Judaism, tr by J E Crowley. Sheffield: Sheffield Academic Press.

Scott, G M 1990. A resynthesis of the primordial and circumstantial approaches to ethnic group solidarity: towards and explanatory model. Ethnic and Racial Studies 13(2), 147-71.

Shils, E A 1957a. Center and periphery: Essays in macrosociology. Selected papers of Edward Shils, vol 2, 111-26. Chicago, IL: Chicago University Press.

Shils, E A 1957b. Primordial, personal, sacred and civil ties. British Journal of Sociology 8, 130-45.

Smith, A D 1986. The ethnic origins of nations. Oxford: Blackwell.

Smith, A D 1994. The politics of culture: Ethnicity and nationalism, in Ingold, T (ed), Companion Encyclopedia of Anthropology, 706-33. London: Routledge.

Stein, S 2004. s v Ethnicity. Encyclopedia of Race and Ethnic Studies, 142-46. London: Routledge. 